\title{
DESAFIOS NA PESQUISA EM EDUCAÇÃO EM ENFERMAGEM NO ÂMBITO BRASILEIRO
}

Vânia Marli Schubert Backes ${ }^{1}$, Mônica Motta Lino²

A área da Enfermagem vem repensando seus modos de fazer, de pesquisar e de educar, refletindo avanços e mudanças no desenvolvimento curricular nos cursos de formação profissional, bem como no ensino de Pós-Graduação e de Graduação. As novas tendências e inovações pedagógicas produzidas dentro da universidade e nos campos de prática, atreladas ao desenvolvimento científico e tecnológico desenvolvido nos Grupos de Pesquisa, têm contribuído e também têm sido produto dos diferentes processos de produção científica e investigativa no setor de Educação em Enfermagem.

Os Grupos de Pesquisa em Educação em Enfermagem-GPEE são estruturas de construção de saber e partilha de ideias congregadas por seus membros, tendo como preceito fundamental a indissociabilidade da educação no setor saúde. A partir das pesquisas desenvolvidas nos GPEE são divulgados os produtos concebidos na construção coletiva à sociedade, que avalia e reitera suas ações em educação em saúde. Muito mais que a produção científico-tecnológica e seu consequente incremento ao quesito produtividade em pesquisa, os Grupos são, genuinamente, espaços que permitem aos seus membros partilhar angústias e inquietações, bem como reconhecer estes sentimentos em seus pares. Permite, ainda, que sejam estabelecidos vínculos de amizade e afeto, encontradas parcerias para o diálogo, realizadas intervenções nas práticas de educação em saúde, a discussão de ideias, o estudo em conjunto, para repensar atitudes, na defesa de um propósito em comum. A produção científica, neste sentido, é um pequeno reflexo da soma de esforços investidos dentro dos GPEE. No entanto, a análise destes produtos é condição sine qua non para a compreensão do panorama "Enfermagem, Educação e Saúde” no Brasil.

O campo de Educação em Enfermagem é dialético e conflitante, visto as constantes reformas do setor saúde no mundo, as mudanças sociais imbricadas nesta estrutura e a não-homogeneidade na formação inicial e permanente de recursos humanos em Enfermagem. As inter-relações entre o mundo do trabalho e a formação de Enfermeiros são pautadas no contexto de realidade e demandas sociais, que têm historicidade e temporalidade. Estas, por sua vez, são percebidas pelas constantes mudanças no modelo de atenção em saúde, como o enfoque atual à promoção da saúde e seus desdobramentos na gestão de políticas públicas.

A formação inicial e permanente de recursos humanos em saúde, em especial da Enfermagem, afeta profundamente a qualidade do cuidado em saúde e representa chave fundamental para a resolução de importantes problemas da realidade. A maior parte destes problemas são consequências de mudanças econômicas, de políticas públicas e das formas sociais do trabalho, tendo relação direta com a Educação em Enfermagem ${ }^{(1)}$. Se a afirmação de que debilidades na formação de recursos humanos em Enfermagem ganha maior visibilidade frente o reconhecimento de sua complexidade, infere-se aqui, a necessidade de aprofundar reflexões e intervenções no conjunto destas questões, bem como de suas consequências.

Responder às problemáticas sociais complexas com práticas hegemônicas (centradas na doença) na educação e na saúde desperta importantes contradições. Assim, optar pela abordagem pedagógica que estimule os futuros enfermeiros a ter postura ativa, crítica e reflexiva durante o processo da construção do conhecimento, compreende um caminho para a transformação e não para a reprodução acrítica da realidade social no âmbito do trabalho. Desvela mudanças sociais( ${ }^{(2)}$.

Com o contexto da globalização e suas consequências econômicas, políticas, sociais e culturais, assim como as inovações tecnológicas e as novas maneiras de gerenciar o processo de produção em saúde, desperta-

\footnotetext{
${ }^{1}$ Doutora em Enfermagem. Docente do Departamento de Enfermagem e do Programa de Pós-Graduação em Enfermagem da Universidade Federal de Santa Catarina-UFSC. Líder do Grupo de Pesquisas em Educação em Enfermagem e Saúde-EDEN. Pesquisadora do Conselho Nacional de Desenvolvimento Científico e Tecnológico-CNPq.E-mail: oivania@ccs.ufsc.br.

${ }^{2}$ Mestre em Enfermagem. Doutoranda do Programa de Pós-Graduação em Enfermagem da UFSC. Bolsista de Doutorado da Coordenação de Aperfeiçoamento de Pessoal de Nível Superior-CAPES. Membro do Grupo de Pesquisas em Educação em Enfermagem e Saúde-EDENUFSC.E-mail: monicafloripa@hotmail.com.
}

Cogitare Enferm 2009 Out/Dez; 14(4):607-11 
se a necessidade de se ampliar a capacidade de intervenção crítico-criativa, de inovar na dinâmica dos serviços e de qualificação profissional - já que educação não transforma o mundo; educação muda pessoas e pessoas transformam o mundo ${ }^{(3)}$. Tal processo de transformação paradigmática apoia-se no fortalecimento do cuidado, com vistas a ampliar a autonomia das populações sobre suas condições de saúde.

A formação e gestão de recursos humanos, neste sentido, não podem ser consideradas uma questão simplesmente técnica. Estas envolvem mudanças nas relações, nos processos, nos produtos e principalmente nas pessoas. São questões técnico-políticas e sociais que implicam em articulações de ações dentro e fora das instituições de saúde. Para ser possível, a Educação em Enfermagem requer investimentos no âmbito da Graduação, da Pós-Graduação e da pesquisa científica, da organização do trabalho, do modelo de cuidado à saúde e do controle social(2).

A pesquisa na sociedade acadêmica e seu corpo de conhecimento científico retratam o que acontece no mundo, todo o tempo. Mas, além disso, ela encontra-se incorporada à vida, nesta mesma sociedade na qual é fruto e objeto. Portanto, os GPEE necessitam pensar diferente, pensar com reflexão, crítica e criatividade, já que a relação teoria e prática é indissociável, é uma unidade. E, pensando diferente, a produção de novos conhecimentos trará reflexos na estrutura constitutiva da força de trabalho em Enfermagem, visto que é capaz de acelerar e qualificar o processo de profissionalização da área e o desenvolvimento da Política de Recursos Humanos em Saúde, apregoada pela Organização Mundial da Saúde e Organização Panamericana de Saúde.

Pensando nesta necessidade, o panorama da produção científica em Educação em Enfermagem no Brasil tem sido investigado pelo Grupo de Pesquisas em Educação em Enfermagem e Saúde-EDEN, da Universidade Federal de Santa Catarina, localizado na Região Sul do Brasil. Pesquisas realizadas no EDEN identificaram em todo o território nacional o registro de 47 Grupos de Pesquisa em Educação, Enfermagem e Saúde, com 418 pesquisadores - hegemonicamente Enfermeiros - cuja maioria tem doutoramento ${ }^{(4)}$. Neste País, a análise da produção científica em Educação em Enfermagem da Região Sul anunciou fortalezas importantes, como a adoção do paradigma pedagógico pautado na concepção libertadora do processo ensinoaprendizagem, com a adoção de referenciais específicos como Paulo Freire. Como fragilidade, foi registrada a necessidade de maior enfoque nas linhas de pesquisas genuínas de Educação em Enfermagem ${ }^{(5)}$.

Alguns dos desafios emergentes que se mostram no Brasil são o desafio interdisciplinar, o desafio do enfoque em linhas de pesquisas, o desafio teórico-ideológico e o desafio político. Estes desafios encontram-se integrados em uma atualidade complexa, que necessita a promoção de alianças e agendas estratégicas conjuntas para a planificação do processo de educação em Enfermagem e do desenvolvimento de ciência e tecnologia em Enfermagem na América Latina. Realidade que se interpõe para a geração de conhecimento pertinente e relevante.

\section{REFERÊNCIAS}

1. Nogueira RP. Resultado do estudo de avaliação de tendências e prioridades sobre recursos humanos em saúde. In: In: Ministério da Saúde (BR). Política de recursos humanos em saúde. Brasil. Brasília: Ministério da Saúde; 2002.

2. Feuerwerker LCM, Lima VV. Os paradigmas da atenção à saúde e da formação de recursos humanos. In: Ministério da Saúde (BR). Política de recursos humanos em saúde. Brasil. Brasília: Ministério da Saúde; 2002.

3. Freire P, Faundez A. Por uma pedagogia da pergunta. Rio de Janeiro: Paz e Terra; 1985.

4. Backes VMS, Canever BP, Ferraz F, Lino MM, Prado ML, Reibnitz KS. Research groups in nursing in the south region part of Brazil. Rev Gaúcha Enferm. 2009 Jun;30(2): in press.

5. Lino MM. Produção científica dos grupos de pesquisa em educação em enfermagem da região Sul do Brasil [dissertação]. Florianópolis (SC): Universidade Federal de Santa Catarina; 2009. 


\section{RESEARCH CHALLENGES IN NURSING EDUCATION IN BRAZIL}

Vânia Marli Schubert Backes ${ }^{1}$, Mônica Motta Lino²

Nursing area is being thinking about its ways of doing, researching and educating, which reflects the advances and changes in the curriculum development of the Nursing professional education, undergraduation and graduation programs. New tendencies and pedagogical innovations produced inside the universities and in practice fields, linked to the scientific and technological development inside the Researche Groups, have being contributing and have being also the product of the various process of scientific and investigative production in the field of Education on Nursing.

Research Groups of Education on NursingRGEN may be considered as knowledge building structures that allow sharing congregated ideas among their members, having as fundamental founding the inseparable characteristics of Education and health in the health sector. From the researches developed among the research groups the production from the collective construction are released to the society, which evaluate them and reaffirm its actions in health education. Much more than the scientific-technological production and its consequent improvement on the research productivity item, Groups are, from the conception, spaces which provide their members to share distresses and torments, as well as to recognize these feelings among their partners. It also allows the development of friendship and attachment bonds; it is the place to find partnerships for dialogue, where interventions on health education practices can be made, as well as the exchange of ideas, the study together to rethink attitudes, defending a common objective. Scientific production, in this sense, is a small reflex of the sum of the efforts that were made inside the RGENs. However these products analysis is a sine qua non condition for the comprehension of the "Nursing, Education and Health" panorama in Brazil.

The Education on Nursing field is dialectics and conflicting because the constant changes in the health sector worldwide, the social changes related to this structure and the non-homogeneous in the initial and permanent formation of Nursing human resources. The inter-relationships between the work world and the Nurses' formation are founded in the context of reality and social demands, which have historicity and temporality. These are perceived by the constant changes on the health care model, as the actual focus to health promotion and its consequences to the public policies management.

Initial and permanent formation of human resources in health, specially Nursing professionals, affects deeply the quality of heath care and it represents a fundamental key to the resolution of some important problems of present days. A great part of these problems are consequences of economical changes, public policies and social ways of work, and they have a straight relationship with Nursing ${ }^{(1)}$. If the affirmation that debilities in the nursing human resources formation earns more visibility when we face its complexity, we infer the need to deepen reflections and interventions in these question's set, as well as their consequences.

To answer these complex social problems with hegemonic practices (centered in illnesses) on health and on education awakes important contradictions. So, to opt to the pedagogical approach that stimulates future nurses to have an active, critical and reflexive attitude during the knowledge construction process is a path to the transformation and not to the non-critical reproduction of the social reality at the work set. It unveils social changes ${ }^{(2)}$.

With the globalization context and it economical, political, social and cultural consequences, as well as the technological innovations and the new ways to manage the health care production process, the need to wide the capacity of critical-creative intervention is awaken. To innovate the dynamics of the health services and the professional qualification - once education doesn't transform the world; education changes people and people transform the world ${ }^{(3)}$. This paradigmatic transformation process is supported by the enhancement of caring, in order to enhance people's autonomy over their health conditions.

Human resources formation and management, in this way, cannot be considered a simply technical question. These questions involve changes in relationships, in processes, in products, and mainly in people. These are technical-political and social questions that demand the articulation of actions, both inside and outside the health organizations. To be possible, Education on Nursing demands funding for Undergraduate and Graduate Programs, Scientific Research, work organization, health care model and social control ${ }^{(2)}$.

Research in academic society and its body of scientific knowledge shows what happens in the world, 
all the time. But, more that this, it can be found incorporated in life, in this same society in which it is product and object. Therefore, the RGENs need to think different, with reflection, criticism and creativity, once the theory and practice relationship is inseparable, it is an unity. And, by thinking different, the production of new knowledge will bring up reflections on the constitutive structure of the work load in Nursing,, once it could accelerate and qualify the professionalization process in the area and the development of the Health Human Resources Policy, which is preached by the World Health Organization and the Pan American Health Organization.

On thinking about this need, the Education on Nursing scientific production panorama in Brazil is being investigated by the Research Group on Education on Nursing and Health, from the Federal University of Santa Catarina, in Southern Brazil. Researches developed at this Group identified, in all Brazilian territory the registry of 47 Research Groups in Education, Nursing and Health, with 418 researches - all nurses - all of them have the Doctor Degree ${ }^{(4)}$. In this country, the analysis of the scientific production in Education on Nursing of Southern Brazil presented important fortresses, as the adoption of the pedagogical paradigm founded on the liberator conception of the teaching-learning process, with the adoption of specific referentials as Paulo Freire. As fragilities, the need of more focus on genuine Education on Nursing researches lines were pointed out ${ }^{(5)}$.

Some of the emerging challenges that could be faced in Brazil are the interdisciplinary challenge of the research lines focus, the theoretical-ideological challenge and the political challenge. These challenges are now integrated in a complex reality, which needs the promotion of alliances and strategical and collective agendas towards planning the Nursing educational process and the development of science and technology in Nursing in the Latin America. This is a reality that is brought to the generation of pertinent and relevant knowledge.

\section{REFERÊNCIAS}

1. Nogueira RP. Resultado do estudo de avaliação de tendências e prioridades sobre recursos humanos em saúde. In: In: Ministério da Saúde (BR). Política de recursos humanos em saúde. Brasil. Brasília: Ministério da Saúde; 2002.

2. Feuerwerker LCM, Lima VV. Os paradigmas da atenção à saúde e da formação de recursos humanos. In: Ministério da Saúde (BR). Política de recursos humanos em saúde. Brasil. Brasília: Ministério da Saúde; 2002.

3. Freire P, Faundez A. Por uma pedagogia da pergunta. Rio de Janeiro: Paz e Terra; 1985.

4. Backes VMS, Canever BP, Ferraz F, Lino MM, Prado ML, Reibnitz KS. Research groups in nursing in the south region part of Brazil. Rev Gaúcha Enferm. 2009 Jun;30(2): in press.

5. Lino MM. Produção científica dos grupos de pesquisa em educação em enfermagem da região Sul do Brasil [dissertação]. Florianópolis (SC): Universidade Federal de Santa Catarina; 2009.

${ }^{1}$ Doutora em Enfermagem. Docente do Departamento de Enfermagem e do Programa de Pós-Graduação em Enfermagem da Universidade Federal de Santa Catarina-UFSC. Líder do Grupo de Pesquisas em Educação em Enfermagem e Saúde-EDEN. Pesquisadora do Conselho Nacional de Desenvolvimento Científico e Tecnológico-CNPq. Endereço: Victor Konder, 54/303. CEP: 88015-663. Florianópolis-SC. E-mail: oivania@ccs.ufsc.br. Tel: 55 (48) 37219787.

${ }^{2}$ Mestre em Enfermagem. Doutoranda do Programa de PósGraduação em Enfermagem da UFSC. Bolsista de Doutorado da Coordenação de Aperfeiçoamento de Pessoal de Nível SuperiorCAPES. Membro do Grupo de Pesquisas em Educação em Enfermagem e Saúde-EDEN-UFSC. Endereço: Getúlio Vargas 2620, Centro, São José-SC. CEP: 88103-400. E-mail: monicafloripa@hotmail.com. Tel: 55 (48) 37219787. 


\section{DESAFIOS EN LA INVESTIGACIÓN EN EDUCACIÓN EN ENFERMERÍA EN EL ÁMBITO BRASILERO}

Vânia Marli Schubert Backes ${ }^{1}$, Mônica Motta Lino²

El área de la Enfermería viene repensando sus modos de hacer, de investigar y de educar, reflejando avances y mudanzas en el desarrollo curricular en los cursos de formación profesional, bien como en la enseñanza de Pos-Graduación y de Graduación. Las nuevas tendencias e innovaciones pedagógicas producidas dentro de la universidad y en los campos de práctica, encajadas al desarrollo científico y tecnológico desarrollado en los Grupos de Investigación, contribuyó y también ha sido producto de los diferentes procesos de producción científica e investigativa en el sector de Educación en Enfermería.

Los Grupos de Investigación en Educación en Enfermería-GIEE son estructuras de construcción de saber y repartición de ideas congregadas por sus miembros, teniendo como precepto fundamental la indisociabilidad de la educación en el sector salud. A partir de las investigaciones desarrolladas en los GIEE son divulgados los productos concebidos en la construcción colectiva a la sociedad, que evalúa y reitera sus acciones en educación en salud. Mucho más que la producción científico-tecnológica y su consecuente incremento al quesito productividad en investigación, los Grupos son, genuinamente, espacios que permiten a sus miembros repartir angustias e inquietudes, bien como reconocer estos sentimientos en sus pares. Permite, todavía, que sean establecidos vínculos de amistad y afecto, encontradas compañías para el diálogo, realizadas intervenciones en las prácticas de educación en salud, la discusión de ideas, el estudio en conjunto, para repensar actitudes, en la defensa de un propósito en común. La producción científica, en este sentido, es un pequeño reflejo de la suma de esfuerzos invertidos dentro de los GIEE. Entretanto, el análisis de estos productos es condición sine qua non para la comprensión del panorama "Enfermería, Educación y Salud” en el Brasil.

El campo de Educación en Enfermería es dialéctico y conflictuado, visto las constantes reformas del sector salud en el mundo, las mudanzas sociales imbricadas en esta estructura y la no-homogeneidad en la formación inicial y permanente de recursos humanos en Enfermería. Las interrelaciones entre el mundo de trabajo y la formación de Enfermeros son pautadas en el contexto de realidad y demandas sociales, que tienen historicidad y temporalidad. Estas, por su vez, son percibidas por las constantes mudanzas en el modelo de atención en salud, como el enfoque actual a la promoción de la salud y sus desdoblamientos en la gestión de políticas públicas.

La formación inicial y permanente de recursos humanos en salud, en especial de la Enfermería, afecta profundamente la calidad del cuidado en salud e representa chave fundamental para la resolución de importantes problemas de la realidad. La mayor parte de estos problemas son consecuencias de mudanzas económicas, de políticas públicas y de las formas sociales del trabajo, teniendo relación directa con la Educación en Enfermería ${ }^{(1)}$. Se a afirmación de que debilidades en la formación de recursos humanos en Enfermería gana mayor visibilidad frente al reconocimiento de su complexidad, infiérase aquí, la necesidad de profundizar reflexiones e intervenciones en el conjunto de estas cuestiones, bien como de sus consecuencias.

Responder a las problemáticas sociales complexas con prácticas hegemónicas (centradas en la enfermedad) en la educación y en la salud despierta importantes contradicciones. Así, optar por el abordaje pedagógico que estimule los futuros enfermeros a tener postura activa, crítica y reflexiva durante el proceso de la construcción del conocimiento, comprende un camino para la transformación y no para la reproducción acrítica de la realidad social en el ámbito del trabajo. Desvela mudanzas sociales ${ }^{(2)}$.

Con el contexto de la globalización y sus consecuencias económicas, políticas, sociales y culturales, así como las innovaciones tecnológicas y las nuevas maneras de gerenciar el proceso de producción en salud, despiértase la necesidad de ampliarse la capacidad de intervención crítico-creativa, de innovar en la dinámica de los servicios y de calificación profesional - ya que educación no transforma el mundo; educación muda personas y personas transforman el mundo ${ }^{(3)}$. Tal proceso de transformación paradigmática apoyase en el fortalecimiento del cuidado, con vistas a ampliar la autonomía de las populaciones sobre sus condiciones de salud.

La formación y gestión de recursos humanos, en este sentido, no pueden ser consideradas una cuestión simplemente técnica. Estas envuelven mudanzas en las relaciones, en los procesos, en los productos y principalmente en las personas. Son cuestiones técnico-políticas y sociales que implican en articulaciones de acciones dentro y fuera de las 
instituciones de salud. Para ser posible, la Educación en Enfermería requiere inversiones en el ámbito de la Graduación, de la Pos-Graduación y de la investigación científica, de la organización del trabajo, del modelo de cuidado a la salud y del control social ${ }^{(2)}$.

La investigación en la sociedad académica y su cuerpo de conocimiento científico retratan lo que pasa en el mundo, todo el tiempo. Pero, además de eso, ella encuéntrase incorporada a la vida, en esta misma sociedad en la cual es fruto y objeto. Por lo tanto, los GIEE necesitan pensar diferente, pensar con reflexión, crítica y creatividad, ya que la relación teoría y práctica es indisociable, es una unidad. Y, pensando diferente, la producción de nuevos conocimientos traerá reflejos en la estructura constitutiva de la fuerza de trabajo en Enfermería, visto que es capaz de acelerar y calificar el proceso de profesionalización del área y el desarrollo de la Política de Recursos Humanos en Salud, apregonada por la Organización Mundial de la Salud y Organización Panamericana de Salude.

Pensando en esta necesidad, el panorama de la producción científica en Educación en Enfermería en el Brasil ha sido investigado por el Grupo de Investigaciones en Educación en Enfermería y Salud EDEN, de la Universidad Federal de Santa Catarina, localizado en la Región Sur del Brasil. Investigaciones realizadas en el EDEN identificaron en todo el territorio nacional el registro de 47 Grupos de Investigación en Educación, Enfermería y Salud, con 418 investigadores - hegemónicamente Enfermeros - cuya mayoría tiene doctoramiento $^{(4)}$. En este País, el análisis de la producción científica en Educación en Enfermería de la Región Sur anunció fortalezas importantes, como la adopción del paradigma pedagógico pautado en la concepción libertadora del proceso enseñanzaaprendizaje, con la adopción de referenciales específicos como Paulo Freire. Como fragilidad, fue registrada la necesidad de mayor enfoque en las líneas de investigaciones genuinas de Educación en Enfermería ${ }^{(5)}$.

Algunos de los desafíos emergentes que se muestran en el Brasil son el desafío interdisciplinar, el desafío del enfoque en líneas de investigaciones, el desafío teórico-ideológico y el desafío político. Estos desafíos se encuentran integrados en una actualidad compleja, que necesita la promoción de alianzas y agendas estratégicas conjuntas para la planificación del proceso de educación en Enfermería y del desarrollo de ciencia y tecnología en Enfermería en la América Latina. Realidad que se interpone para la generación de conocimiento pertinente y relevante.

\section{REFERÊNCIAS}

1. Nogueira RP. Resultado do estudo de avaliação de tendências e prioridades sobre recursos humanos em saúde. In: In: Ministério da Saúde (BR). Política de recursos humanos em saúde. Brasil. Brasília: Ministério da Saúde; 2002.

2. Feuerwerker LCM, Lima VV. Os paradigmas da atenção à saúde e da formação de recursos humanos. In: Ministério da Saúde (BR). Política de recursos humanos em saúde. Brasil. Brasília: Ministério da Saúde; 2002.

3. Freire P, Faundez A. Por uma pedagogia da pergunta. Rio de Janeiro: Paz e Terra; 1985.

4. Backes VMS, Canever BP, Ferraz F, Lino MM, Prado ML, Reibnitz KS. Research groups in nursing in the south region part of Brazil. Rev Gaúcha Enferm. 2009 Jun;30(2): in press.

5. Lino MM. Produção científica dos grupos de pesquisa em educação em enfermagem da região Sul do Brasil [dissertação]. Florianópolis (SC): Universidade Federal de Santa Catarina; 2009.

${ }^{1}$ Doutora em Enfermagem. Docente do Departamento de Enfermagem e do Programa de Pós-Graduação em Enfermagem da Universidade Federal de Santa Catarina-UFSC. Líder do Grupo de Pesquisas em Educação em Enfermagem e Saúde-EDEN. Pesquisadora do Conselho Nacional de Desenvolvimento Científico e Tecnológico-CNPq. Endereço: Victor Konder, 54/303. CEP: 88015-663. Florianópolis-SC. E-mail: oivania@ccs.ufsc.br. Tel: 55 (48) 37219787.

${ }^{2}$ Mestre em Enfermagem. Doutoranda do Programa de PósGraduação em Enfermagem da UFSC. Bolsista de Doutorado da Coordenação de Aperfeiçoamento de Pessoal de Nível SuperiorCAPES. Membro do Grupo de Pesquisas em Educação em Enfermagem e Saúde-EDEN-UFSC. Endereço: Getúlio Vargas 2620, Centro, São José-SC. CEP: 88103-400. E-mail: monicafloripa@hotmail.com. Tel: 55 (48) 37219787. 